\title{
23. GEOCHEMICAL RESULTS FOR BASALTS FROM SITES 253 AND 254
}

\author{
Fred A. Frey and Chien Min Sung, Department of Earth and Planetary Science, \\ Massachusetts Institute of Technology, Cambridge, Massachusetts
}

\section{INTRODUCTION}

Deep Sea Drilling Project Sites 253 and 254 are on the Ninetyeast Ridge (Site 253 on the western flank at $24^{\circ} 52.65^{\prime} \mathrm{S}, 87^{\circ} 21.97^{\prime} \mathrm{E}$; and Site 254 near the intersection with Broken Ridge at the southern end of the Ninetyeast Ridge at $\left.30^{\circ} 58.15^{\prime} \mathrm{S}, 87^{\circ} 53.72^{\prime} \mathrm{E}\right)$. The igneous rocks at the Ninetyeast Ridge sites (Sites 214 and 216) drilled on DSDP Leg 22 are quite different from typical mid-ocean-ridge basalt (Hekinian, 1974 and Thompson et al., 1974). The geochemical features which characterize the basalt at Sites 214 and 216 are:

1) High abundances of large-ion lithophile (LIL) trace elements such as strontium, barium, zirconium, and light rare-earth elements (REE); these elements are normally depleted in mid-ocean-ridge basalt (Table 1 and Figure 1).

2) High abundances of iron (total iron as $\mathrm{FeO}>13$ wt. \%) and titanium coupled with low abundances of calcium and magnesium (Table 2 and Figure 2).

3) Low abundances of trace elements such as chromium and nickel; these elements are normally enriched in mafic minerals (Table 1).

4) The association of oceanic andesites with the ferrobasalt at Site 214 (Figure 2).

Based on geophysical and age data, Sclater et al., 1974 and Bowin (1973) have established that the Ninetyeast Ridge does not mark the boundary between the Indian Ocean plate and the Wharton Basin plate, but rather it is a feature of the Indian Ocean plate. Bowin (1973) suggested that the Ninetyeast Ridge originated as a result of emplacement of gabbro and serpentinized peridotite beneath normal ocean crustal layers. He postulated that the localized emplacement was the result of a mantle plume which did not have conditions appropriate for formation of a large volcanic structure such as Iceland. Sclater et al., 1974 concluded that a plume or "hot spot" model could explain the origin of the Ninetyeast Ridge north of $8^{\circ} \mathrm{S}$, but that south of $8^{\circ} \mathrm{S}$ a leaky transform-fault model was more likely.

Hekinian (1974) demonstrated that DSDP Leg 22 Sites 214 and 216 have geochemical similarities to the Indian Ocean islands of St. Paul and Amsterdam. Thompson et al. (1974) noted that Site 216 north of $8^{\circ} \mathrm{S}$ and Site 214 south of $8^{\circ} \mathrm{S}$ have geochemical similarities, and further, that their geochemical characteristics are the same features which distinguish Icelandic basalt from Reykjanes Ridge basalt (Schilling, 1973). Clearly, a petrological-geochemical comparison of the basalt of Leg 26 (southern Ninetyeast Ridge) Sites 253 and 254 with the basalt of Leg 22 (northern Ninetyeast Ridge) Sites 214 and 216 provides important infor- mation for understanding the origin and development of the Ninetyeast Ridge.

\section{RESULTS}

Four basaltic samples from Sites 253 and 254 were analyzed for trace elements (scandium, chromium, cobalt, hafnium, tantalum, and REE) by instrumental neutron activation analysis (Table 1). Petrographical descriptions, major-element data (Table 2), and some trace-element data for these samples are presented by Kempe (this volume, Chapter 14).

\section{Site 253}

Sample $253-24-1,84-85 \mathrm{~cm}$ is an altered scoriaceous glassy basalt from a thin flow in an ash sequence. Several hundred meters of ash were cored below this flow so it is not a sample of basement rock. Olivine and plagioclase are phenocryst and microphenocryst phases in the glass. In major-element composition this basalt is more like Mid-Indian Ocean Ridge basalt (MIORB) than basalt from Sites 214 and 216 (Table 2). On a normative basis, Kempe (1973 and this volume, Chapter 14) has classified this rock as a quartz tholeiite. It is important to note that each of the four Leg 26 samples we studied is highly altered (cf. $\mathrm{H}_{2} \mathrm{O}+\mathrm{CO}_{2}$ content in Table 2). Thompson (in press) has summarized data on the effects of low-temperature alteration on oceanic basalt. The major-element effects are increases in $\mathrm{Fe}_{2} \mathrm{O}_{3}$, potassium, and volatiles $\left(\mathrm{H}_{2} \mathrm{O}\right.$ and $\left.\mathrm{CO}_{2}\right)$ accompanied by decreases in $\mathrm{CaO}, \mathrm{MgO}$, and $\mathrm{SiO}_{2}$. The high degree of oxidation $\left(\mathrm{Fe}_{2} \mathrm{O}_{3} / \mathrm{FeO}=0.6\right)$ and high $\mathrm{K}_{2} \mathrm{O}$ abundance of this basalt relative to MIORB probably have resulted from alteration. When the normative mineralogy has been recalculated on the basis of $\mathrm{Fe}^{+3} / \mathrm{Fe}^{+2}+\mathrm{Fe}^{+3}=0.1$ this basalt lies very close to the silica-saturation boundary in the hypersthene-diopside-olivine ternary. The majority of dredged oceanic-ridge basalt lies within this normative ternary (Chayes, 1972).

This Site 253 basalt is markedly higher in $\mathrm{Al}_{2} \mathrm{O}_{3}$ and lower in total iron and $\mathrm{TiO}_{2}$ abundances compared to the basalts of Sites 214 and 216 (Table 2). Also the chromium abundance in this basalt is a factor of 10 higher than in basalt from Sites 214 and 216 (Table 1). These differences almost certainly reflect differences in the original magmas.

The abundances of transition-metal trace elements (scandium, chromium, and cobalt) in Section 253-24-1 basalt are similar to MIORB (Table 1), but, as at Sites 214 and 216, the LIL elements (such as light REE, zirconium, hafnium, and tantalum) are enriched in this basalt compared to the tholeiitic basalts typical of oceanic ridges (Table 1 and Figure 1). Some LIL- 
TABLE 1

Trace Element Abundances in Ninetyeast Ridge Basalts ${ }^{\mathrm{a}}$ (ppm)

\begin{tabular}{|c|c|c|c|c|c|c|c|}
\hline \multirow[b]{2}{*}{ Element } & \multicolumn{2}{|r|}{ Leg 22} & \multicolumn{4}{|c|}{ Leg 26} & \multirow[b]{2}{*}{$\begin{array}{c}\text { Central } \\
\text { Indian Ridge }\end{array}$} \\
\hline & $\begin{array}{l}\text { Site } \\
214\end{array}$ & $\begin{array}{c}\text { Sample } \\
216-38, C C\end{array}$ & $\begin{array}{c}\text { Sample } \\
253-24-1,84-85 \mathrm{~cm}\end{array}$ & $\begin{array}{c}\text { Sample } \\
253-58-1,2-7 \mathrm{~cm}\end{array}$ & $\begin{array}{c}\text { Sample } \\
254-36-3,95-97 \mathrm{~cm}\end{array}$ & $\begin{array}{c}\text { Sample } \\
254-38-1,115-117 \mathrm{~cm}\end{array}$ & \\
\hline $\mathrm{Cr}$ & 43 & 25 & 460 & 640 & 360 & 140 & $180-460$ \\
\hline Co & 61 & 47 & 56 & 40 & 51 & 53 & 26-80 \\
\hline $\mathrm{Ni}^{\mathrm{C}}$ & 53 & 45 & - & 310 & 200 & - & $130-320$ \\
\hline $\mathrm{Ta}$ & 1.9 & 3.0 & 0.66 & 0.11 & 0.71 & 0.42 & $<0.5$ \\
\hline $\mathrm{La}$ & 8.4 & 14.7 & 9.2 & 7.8 & 11.1 & 7.2 & $2-4$ \\
\hline $\mathrm{Ce}$ & 21.3 & 29.0 & 22.2 & 17.3 & 25.7 & 17.0 & $5.7-12$ \\
\hline $\mathrm{Nd}$ & 15.3 & 21.0 & 11.1 & 12.3 & 18.2 & 12.9 & $8.4-12.4$ \\
\hline $\mathrm{Sm}$ & 5.1 & 5.3 & 3.1 & 3.3 & 5.3 & 4.1 & $2.5-5$ \\
\hline $\mathrm{Eu}$ & 1.7 & 1.6 & 1.2 & 1.1 & 1.8 & 1.2 & $1-1.6$ \\
\hline
\end{tabular}

${ }^{\mathrm{a}}$ Data except $\mathrm{Ni}$ and $\mathrm{Zr}$ obtained by instrumental neutron activation analysis, precision and accuracy $\pm 10 \%$ for all but $\mathrm{Tb}$ and $\mathrm{Lu} \pm 25 \%$.

${ }^{b}$ Average of 3 from Thompson et al. (in press).

${ }^{\mathrm{c}}$ Data from Kempe (this volume).

${ }^{\mathrm{d}}$ Sung and Frey, unpublished data.

${ }^{e}$ Abundance range for Sc, Cr, Co, Ni, Zr from Cann (1970), Engel and Fisher (1969); Hf and Ta maximum for ridge basalts from Frey et al. (in press, $\left.{ }^{b}\right)$; REE range from Schilling (1971).

element enrichment may be caused by low-temperature alteration (e.g., Hart, 1971; Thompson, 1974; Frey et al., in press). For example, potassium, rubidium, and cesium abundances are markedly increased by slight alteration; strontium and barium by moderate alteration; and light REE by severe alteration; whereas abundances of elements such as zirconium and hafnium appear to be only slightly affected even by severe alteration (Cann, 1970; Thompson, 1973). Because even zirconium and hafnium are enriched in Section 253-24-1 we suggest that this basalt is tholeitic in majorelement composition (i.e., similar to basalts formed at spreading ridges) but that it is enriched in LIL elements. It is a depletion in LIL elements which is the most distinctive feature of basalts formed at active oceanicridge spreading centers, but tholeiitic basalts with LILelement enrichment have been found previously, e.g., in the Atlantic Ocean at $45^{\circ} \mathrm{N}$ on the Mid-Atlantic Ridge (Muir et al., 1964; Frey et al., 1968) and at Sites 2-10 of DSDP Leg 2 (Frey et al., 1973, in press). These conclusions about the magma chemistry for the Sample 253-24-1, 84-85 $\mathrm{cm}$ basalt are tentative until studies of fresh glass are made.

Sample 253-58-1, 2-7 cm is a sample of the porphyritic olivine basalt in which this hole terminated. The rock is very altered and abundant olivine has been replaced by talc and serpentine. The most distinctive chemical feature of this basalt is its high $\mathrm{MgO}$ content (14.8 wt. \% on anhydrous basis) which reflects the high modal abundance $(\sim 15 \%)$ of olivine (Kempe, this volume, Chapter 14). Other major-element abundances such as low $\mathrm{Na}_{2} \mathrm{O}$ and $\mathrm{TiO}_{2}$ (Table 2) indicate that this basalt is either a picritic cumulate or a basalt which has undergone very little olivine fractionation such as found on DSDP Leg 3, Sites 14 and 18 (Frey et al., in press). The high chromium and nickel abundances (Table 1) coupled with low zirconium, hafnium, tantalum, and REE abundances (Table 1 and Figure 1) also indicate a cumulate rock or a primitive relatively unfractionated magma. Despite the low abundances of LIL elements, this basalt is relatively enriched in light REE (Figure 1) similar to the upper flow (Sample 253-24-1, 84-85 cm). There is a possibility that this lower basalt is an olivine cumulate genetically related to basalts such as the overlying flows. For example, addition of $15 \%$ olivine (FOss) to the basalt in Sample 253-24-1, 84-85 cm would account for the $\mathrm{MgO}$ enrichment in the basalt in Sample 253-58-1, 2-7 cm. Qualitatively the lower abundance of $\mathrm{SiO}_{2}, \mathrm{Al}_{2} \mathrm{O}_{3}, \mathrm{CaO}$, and $\mathrm{Na}_{2} \mathrm{O}$, and higher abundances of $\mathrm{FeO}^{*}$ and $\mathrm{MgO}$ in Section 253-58-1 are consistent with olivine differentiation. We suggest that olivine accumulation is the explanation for the high $\mathrm{MgO}$ content in this basalt. Olivine accumulation would decrease the LIL-element abundances in the cumulate rock without causing significant relative REE fractionation. Again, any interpretation of the present data is tentative because of the high degree of alteration. Electronmicroprobe analyses of fresh glass are needed to definitely establish whether this basalt is a cumulate or if it represents a mafic magma such as found in the Atlantic on Leg 3 (Frey et al., 1973, in press). Both of the basalts studied from Site 253 have low $\mathrm{FeO}^{*} / \mathrm{MgO}$ ratios $(<0.9$, Table 2$)$. Since alteration processes tend to increase $\mathrm{FeO}^{*} / \mathrm{MgO}$ ratios (Thompson, 1973), this 


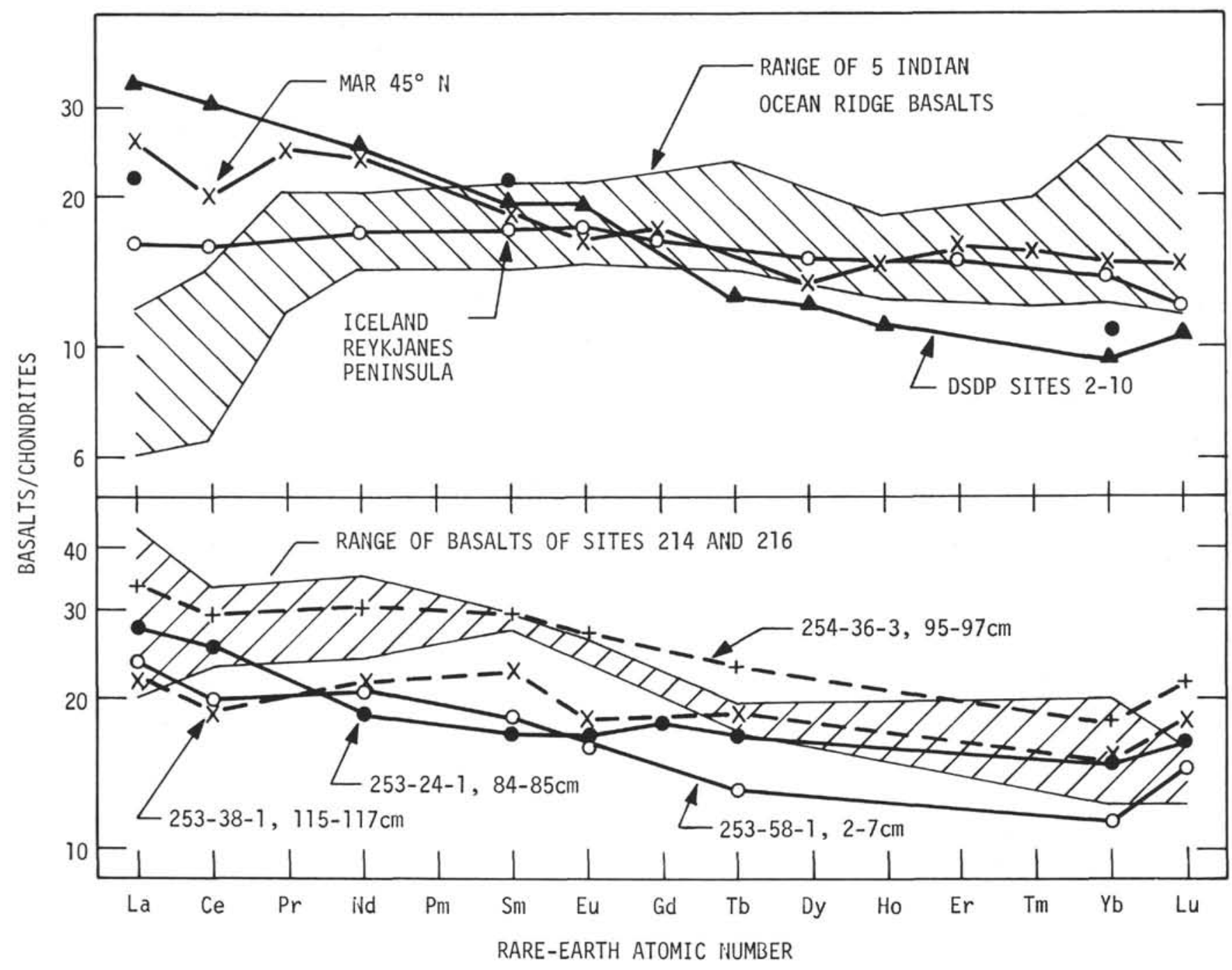

Figure 1. Top - Comparison of REE abundances in tholeiitic basalts to a chondrite average. Basalts from MAR $45^{\circ} N($ Frey et al., 1968; Nichols and Islam, 1971), Reykjanes Peninsula, Iceland (Shimokawa and Masuda, 1972; for La, Sm, and Yb are averages from Schilling, 1973) and DSDP Site 2-10 (Frey et al., in press, $a$. b) are enriched in light REE relative to oceanic-ridge tholeiites. Bottom - Comparison of Ninetyeast Ridge basalts (DSDP Leg 22 Sites 214 and 216 and DSDP Leg 26 Sites 253 and 254) to a chondrite average.

parameter clearly distinguishes these basalts from those at Ninetyeast Ridge, Sites 214 and 216 (Table 2).

\section{Site 254}

At Site $254, \sim 10$ meters of basalt were recovered. Three types of basalt have been identified on the basis of petrography (Kempe, this volume, Chapter 14). Sample 254-36-3, 95-97 cm is an example of the stratigraphically highest basalt which is coarsely hyalophitic lava containing large $(3 \mathrm{~mm})$ feldspar and ophitic clusters of pyroxene and feldspar in an altered glassy matrix. Sample 254-38-1, 115-117 cm is from the lowest unit which consists of autobrecciated, very altered basalts. In this sample montmorillonite (determined by X-ray diffraction) is the dominant mineral. The major-element data indicate the presence of almost $8 \mathrm{wt} . \% \mathrm{H}_{2} \mathrm{O}$ (Table 2 ). Despite the abundance of montmorillonite, the major-element abundances retain features characteristic of an igneous basalt rather than clay-alteration products. For example, although the $\mathrm{K}_{2} \mathrm{O}$ abundance is the highest of the four samples studied, the $\mathrm{K}_{2} \mathrm{O} / \mathrm{Na}_{2} \mathrm{O}$ ratio is $<1$, unlike clay minerals in marine basalts (Melson and Thompson, 1973). However, the low $\mathrm{CaO}$ content of this sample is certainly a result of alteration since $\mathrm{CaO}$ loss is characteristic of low-temperature alteration (Thompson, 1973; Melson and Thompson, 1973). Compared to the Site 253 basalts both of the Site 254 basalts have higher $\mathrm{TiO}_{2}$, total iron, and lower $\mathrm{Al}_{2} \mathrm{O}_{3}$ abundances. Because these contrasts are not correlated with degree of alteration, they probably represent fundamental differences in the original magmas. These features (high $\mathrm{TiO}_{2}$ and total iron, low $\left.\mathrm{Al}_{2} \mathrm{O}_{3}\right)$ are characteristic of the basalt from Sites 214 and 216. The Site 254 basalt appears to be intermediate 
TABLE 2

Comparison of Major Element Abundances in Indian Ocean Basalts ${ }^{\mathrm{a}}$

\begin{tabular}{|c|c|c|c|c|c|c|c|c|c|}
\hline \multirow[b]{2}{*}{ Element } & \multirow{2}{*}{$\begin{array}{l}\text { Site } \\
214^{b}\end{array}$} & \multirow{2}{*}{$\begin{array}{l}\text { Site } \\
216^{c}\end{array}$} & \multicolumn{2}{|c|}{ Site $253^{\mathrm{d}}$} & \multicolumn{2}{|c|}{ Site $254^{\mathrm{d}}$} & \multirow{2}{*}{$\begin{array}{l}\text { Carlsberg } \\
\text { Ridge }\end{array}$} & \multirow{2}{*}{\multicolumn{2}{|c|}{ St. Paul Island }} \\
\hline & & & $24-1,84-85 \mathrm{~cm}$ & $58-1,2-7 \mathrm{~cm}$ & $36-3,95-97 \mathrm{~cm}$ & $38-1,115-117 \mathrm{~cm}$ & & & \\
\hline $\mathrm{SiO}_{2}$ & 48.10 & 49.50 & 52.20 & 46.60 & 47.20 & 49.20 & 49.70 & 48.40 & 48.70 \\
\hline $\mathrm{Al}_{2} \mathrm{O}_{3}$ & 14.90 & 13.50 & 18.30 & 16.70 & 14.80 & 14.30 & 16.40 & 12.60 & 18.40 \\
\hline $\mathrm{FeO}^{* a}$ & 14.60 & 13.80 & 6.92 & 10.50 & 12.70 & 11.50 & 10.10 & 16.70 & 12.20 \\
\hline $\mathrm{MgO}$ & 6.45 & 6.57 & 7.87 & 14.80 & 8.10 & 11.10 & 7.70 & 5.17 & 4.32 \\
\hline $\mathrm{CaO}$ & 9.04 & 8.79 & 9.67 & 8.38 & 9.94 & 7.20 & 10.94 & 8.18 & 10.1 \\
\hline $\mathrm{Na}_{2} \mathrm{O}$ & 2.75 & 2.57 & 3.05 & 1.49 & 2.63 & 2.11 & 3.05 & 3.02 & 2.92 \\
\hline $\mathrm{K}_{2} \mathrm{O}$ & 0.37 & 0.90 & 0.32 & 0.40 & 0.16 & 0.74 & 0.18 & 0.46 & 0.45 \\
\hline $\mathrm{TiO}_{2}$ & 2.35 & 2.75 & 0.98 & 0.74 & 2.62 & 1.72 & 1.67 & 3.58 & 1.76 \\
\hline $\mathrm{P}_{2} \mathrm{O}_{5}$ & 0.19 & 0.22 & 0.35 & 0.09 & 0.28 & 0.18 & 0.08 & 0.82 & 0.35 \\
\hline $\mathrm{FeO} * / \mathrm{MgO}$ & 2.26 & 2.10 & 0.88 & 0.71 & 1.65 & 1.13 & 1.31 & 3.23 & 2.82 \\
\hline $\mathrm{H}_{2} \mathrm{O}+\mathrm{CO}_{2}$ & 5.83 & 3.79 & 5.94 & 7.51 & 5.46 & 8.25 & 1.09 & 2.25 & 0.60 \\
\hline
\end{tabular}

${ }^{\mathrm{a}}$ Values in wt. \% calculated on anhydrous basis.

b Average of 6 (Hekinian, in press).

Average of 7 (Hekinian, in press).

$\mathrm{d}_{\text {Kempe (this volume). }}$

e Average of 6 (Cann, 1969).

f Olivine basalts from St. Paul Island (Girod et al., 1971).

$\mathrm{g}_{\mathrm{FeO}} *$ is all $\mathrm{Fe}$ calculated at $\mathrm{FeO}$.

between the group at Sites 214 and 216 and that at Site 253. For example, basalt at Sites 214 and 216 have $\mathrm{FeO}^{*} / \mathrm{MgO}$ ratios $>2$ and Site 253 basalt have $\mathrm{FeO}^{*} / \mathrm{MgO}$ ratios $<1$, whereas Site 254 basalt have $\mathrm{FeO}^{*} / \mathrm{MgO}$ ratios $<1$ but $>2$. In a comparison of the Site 254 basalt, Sample 254-36-3, 95-97 cm has a higher $\mathrm{FeO}^{*} / \mathrm{MgO}$ ratio, higher $\mathrm{REE}$, hafnium, and tantalum abundances, and a higher degree of light REE enrichment (Figure 1) than Sample 254-38-1, 115-117 cm. These major- and trace-element trends are expected of crystal/liquid separation processes and indicate that Sample 254-36-1, 95-97 cm is a more fractionated basalt. The higher chromium abundance in Sample 254-36-3, $95-97 \mathrm{~cm}$ is not consistent with this interpretation. As with the Site 253 basalt, the interpretation of igneous processes by use of chemical data from altered basalt is tenuous until the available unaltered glasses have been studied.

\section{CONCLUSIONS}

The studies of crystalline altered basalt from the Ninetyeast Ridge (Leg 22, Sites 214 and 216, Hekinian, 1973; 1974; Thompson et al., 1974; Leg 26, this volume) suggest that at least three types of igneous rock occur at the crest of the Ninetyeast Ridge:

1) Oceanic andesite (Site 214) which is readily recognized by an intermediate $\mathrm{SiO}_{2}$ content $(>55 \%$ $\mathrm{SiO}_{2}$ ) and a higher alkali-metal content (Figure 2) when compared to basalt.

2) Iron-rich tholeiitic basalts (Sites 214, 216, and 254) which are readily recognized by their high $\mathrm{FeO}^{*} / \mathrm{MgO}$ ratios (Table 1 and Figure 2).

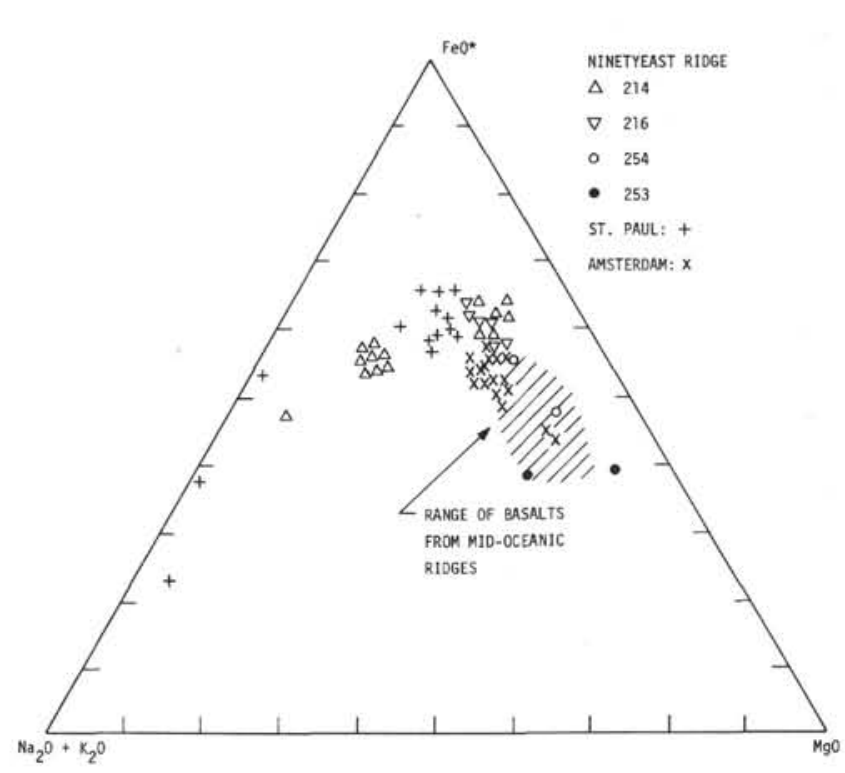

Figure 2. $\mathrm{FMA}$ diagram $(\mathrm{FeO}$ is total iron as $\mathrm{FeO}$, units are $w t . \%)$ illustrating relative iron enrichment in Ninetyeast Ridge basalts and basalts from Amsterdam and St. Paul islands. The $\mathrm{Na}_{2} \mathrm{O}+\mathrm{K}_{2} \mathrm{O}$-rich rocks are the oceanic andesites at Site 214 and St. Paul Island. Range of midoceanic-ridge basalts from Hekinian (in press).

3) Tholeiitic basalts (Site 253) similar in majorelement abundances to oceanic-ridge tholeiites (Figure 2 and Table 2), but containing relatively high abundances of LIL elements such as light REE, zirconium, and 
hafnium. These basalts are readily distinguished from LIL-element-depleted tholeiites by their REE distributions (Figure 1).

These three types of igneous rock are also known to exist in Iceland (Schilling, 1973; Jakobsson, 1972; Baldridge et al., 1973), the Faeroe Islands (Schilling, personal communication, and Noe-Nygaard and Rasmussen, 1968), $45^{\circ} \mathrm{N}$ (near the Azores) on the MidAtlantic Ridge (Muir et al., 1964; Aumento, 1969; Aumento and Loncarevic, 1969; Frey et al., 1968; and Nicholls and Islam, 1971) and in the Galapagos Islands (McBirney and Williams, 1969). The consistent appearance of these three rock types implies some similarity to the petrogenetic processes involved in forming oceanic islands and the aseismic Ninetyeast Ridge and a dissimilarity with the petrogenetic processes forming active spreading ridges away from oceanic islands. Hekinian $(1973,1974)$ has previously suggested that the type of volcanism encountered on aseismic ridges is similar to that of islands associated with ridges. Morgan (1971, 1972) has inferred that areas such as Iceland, Azores, and the Galapagos have formed as a result of a mantle plume.

Amsterdam and St. Paul islands, located southwest of the southern end of the Ninetyeast Ridge, may have a tectonic relationship to the Ninetyeast Ridge (Sclater et al., 1974). Morgan (1972) has also designated these islands as representing mantle-plume activity. The three igneous rock types described above are abundant on these islands (oceanic andesite and iron-rich tholeiites on St. Paul Island, Reinisch, 1909 and Girod et al., 1971; LIL-element-enriched tholeiite on Amsterdam, Gunn et al., 1971; see Figure 2). As at Iceland, the basalts on St. Paul Island have $\mathrm{Sr}^{87} / \mathrm{Sr}^{86}$ ratios higher than those observed for oceanic-ridge basalts $(>0.703$ on Iceland, Hart et al., 1973; >0.704 on St. Paul Island, Girod et al., 1971). Based on the difference in strontium isotope ratios, Schilling (1973) has concluded that two different mantle magma sources are involved in generating Icelandic basalt and Reykjanes Ridge basalt. Schilling (1971) and Frey et al. (in press) have demonstrated the extreme difficulty of deriving the light-REE enrichment of Icelandic and Mid-Atlantic Ridge $45^{\circ} \mathrm{N}$ basalt from light-REE-depleted basalt characteristic of oceanic ridges. Girod et al. (1971) concluded that (1) the basalts of St. Paul Island separated from their mantle source at depths greater than oceanic-ridge basalt and (2) fractional crystallization was much more extensive at St. Paul Island (forming iron-rich basalt and oceanic andesites) than at oceanic ridges. Since sampling at four sites on the Ninetyeast Ridge has returned the rock types typical of oceanic islands like Iceland and Amsterdam-St. Paul, we suggest a similar model for the origin of the Ninetyeast Ridge. The geochemical data available for Ninetyeast Ridge rocks are those from altered rocks. Detailed testing of the model (separate magma source but more extensive fractional crystallization) requires future studies of unaltered glasses from cores from Sites 214, 216, 253, and 254.

\section{ACKNOWLEDGMENTS}

We thank Dr. D. R. C. Kempe for supplying the samples and providing access to his data. This research was supported by NSF Grant GA 31244 .

\section{REFERENCES}

Aumento, F., 1969. Diorites from the Mid-Atlantic Ridge at $45^{\circ} \mathrm{N}$ : Science, v. 165 , p. 1112.

Aumento, F. and Loncarevic, B. D., 1969. The Mid-Atlantic Ridge near $45^{\circ} \mathrm{N}$. III Bald Mountain: Canadian J. Earth Sci., v. 6, p. 11.

Baldridge, W. S., McGetchin, T. R., and Frey, F. A., 1973 Magmatic evolution of Hekla, Iceland: Contrib. Mineral. Petrol., v. 42, p. 245.

Bowin, C., 1973. Origin of the Ninetyeast Ridge from studies near the equator: J. Geophys. Res., v. 78, p. 6029.

Cann, J. R., 1969. Spilites from the Carlsberg Ridge, Indian Ocean: J. Petrol., v. 10, p. 1.

1970. Rb, Sr, $\mathrm{Y}, \mathrm{Zr}$, and $\mathrm{Nb}$ in some ocean floor basaltic rocks: Earth Planet. Sci. Lett., v. 10, p. 7.

Chayes, F., 1972. Silica saturation in Cenozoic basalt: Roy. Soc. London Phil. Trans., Ser. A, v. 271, p. 285.

Engel, C. G. and Fisher, R. L., 1969. Lherzolite, anorthosite, gabbro and basalt dredged from the Mid-Indian Ocean Ridge: Science, v. 166, p. 1136.

Frey, F. A., Bryan, W. B., Thompson, G., and Roy, S., 1973. Petrological and geochemical results for basalts from DSDP Legs 2 and 3, EOS, v. 54, p. 1004.

Frey, F. A., Haskin, M. A., Poetz, J. A., and Haskin, L. A., 1968. Rare earth abundances in some basic rocks: J. Geophys. Res., v. 73, p. 6085.

Frey, F. A., Thompson, G., and Bryan, W. B., in press. Atlantic Ocean Floor Basalts: Petrology and geochemistry of basalts from Legs 2 and 3 of the Deep Sea Drilling Project: J. Geophys. Res.

Girod, M., Camus, G., and Vialette, Y., 1971. Sur la présence de tholeiites à l'ile Saint-Paul (Océan Indien): Contrib. Mineral. Petrol., v. 33, p. 108.

Gunn, B. M., Abranson, L. E., Nougier, J., Watkins, N. D., and Hajash, A., 1971. Amsterdam Island, an isolated volcano in the southern Indian Ocean: Contrib. Mineral. Petrol., v. 32 , p. 79 .

Hart, S. R., 1971. K, Rb, Cs, Sr, and Ba contents and $\mathrm{Sr}$ isotope ratios of ocean floor basalts: Roy. Soc. London Phil. Trans., Ser. A, v. 268, p. 573.

Hart, S. R., Schilling, J. G., and Powell, J. L., 1973. Basalts from Iceland and along the Reykjanes Ridge: $\mathrm{Sr}$ isotope geochemistry: nature Phys. Sci., v. 246, p. 104.

Hekinian, R., 1973. Petrology of rocks from the Northeastern Indian basins and Ninetyeast Ridge: EOS., v. 54, p. 1006.

1974. Petrology of rocks from Leg 22 of Glomar Challenger in the northeastern Indian Ocean. In von der Borch, C. C., Sclater, J. G., et al., Initial Reports of the Deep Sea Drilling Project, Volume 22: Washington (U.S. Government Printing Office), p. 413-448

Jakobsson, S. P., 1972. Chemistry and distribution pattern of recent basaltic rocks in Iceland: Lithos, v. 5, p. 365 ,

Kempe, D. R. C., 1973. Basalts from the southern Indian Ocean: EOS, v. 54, p. 1008.

McBirney, A. R. and Williams, H., 1969. Geology and petrology of the Galapagos Islands: Geol. Soc. Am. Mem. 118.

Melson, W. G. and Thompson, G., 1973. Glassy abyssal basalts, Atlantic sea floor near St. Paul's Rocks; 
Petrography and composition of secondary clay minerals: Geol. Soc. Am. Bull., v. 84, p. 703.

Morgan, W. J., 1971. Convection plumes in the lower mantle: Nature, v. 230, p. 42.

1972. Plate motions and deep mantle convection, Geol. Soc. Am. Mem. 132, p. 7-22.

Muir, I. D., Tilley, C. E., and Scoon, J. H., 1964. Basalts from the northern part of the rift zone of the Mid-Atlantic Ridge: J. Petrol., v. 5, p. 409.

Nicholls, G. D. and Islam, M. R., 1971. Geochemical investigations of basalts and associated rocks from the ocean floor and their implications: Roy. Soc. London Phil. Trans., Ser. A, v. 268 , p. 469.

Noe-Nyggard, A. and Rasmussen, J., 1968. Petrology of a 3,000 metre sequence of basaltic lavas in the Faeroe Islands: Lithos, v. 1, p. 286.

Reinisch, R., 1909. Gesteine von St. Paul and NeuAmsterdam: Deutsche Süd Polar Expedition (1901-1903), Bd. II, S. 385.

Schilling, J. G., 1971. Sea-floor evolution: rare-earth evidence: Roy. Soc. London Phil. Trans., Ser. A, v. 268, p. 663.
1973. Iceland mantle plume: Geochemical Study of Reykjanes Ridge: Nature, v. 242, p. 565.

Sclater, J. G., von der Borch, C. C., et al., 1974. Regional synthesis of the results from JOIDES Leg 22 in the eastern Indian Ocean. In von der Borch, C. C., Sclater, J. G., et al., Initial Reports of the Deep Sea Drilling Project, Volume 22: Washington (U.S. Government Printing Office), p. 815832.

Shimokawa, T. and Masuda, A., 1972. Rare-earths in Icelandic neovolcanic rocks, Contrib. Mineral. Petrol., v. 37, p. 39.

Thompson, G., in press. A geochemical study of the lowtemperature interaction of sea-water and oceanic igneous rocks: EOS, v. 54, p. 1015.

Thompson, G., Bryan, W. B., Frey, F. A., and Sung, C. M., in press. Petrology and geochemistry of basalts and related rocks from Sites 214, 215, 216, DSDP Leg 22, Indian Ocean. In von der Borch, C. C., Sclater, J. G., et al., Initial Reports of the Deep Sea Drilling Project, Volume 22: Washington (U.S. Government Printing Office). 